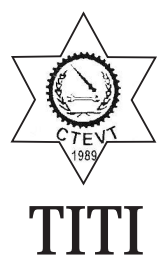

\title{
Educational Aspiration, Dropout and TEVT
}

\author{
Laxman Acharya \\ PhD Scholar in Development Studies \\ Kathmandu University, School of Education \\ Hattiban, Lalitpur, Nepal \\ Email for correspondence: laxmanacharya.np@gmail.com
}

\begin{abstract}
This paper explores and discusses the root causes of dropout in an ethnic community in Nepal and then suggests of mandating technical and vocational education in secondary level education as one of the solutions that increases both efficiency and output of education system. In doing so, I carried out an ethnographic research as the part of my Ph.D, in ethnic community of Tamang people in one rural areas of Kathmandu district. I applied prolong field observation and in depth interview to explore their perception regarding school education. I came with the understanding that people had very low level of aspiration from existing school education. People were experienced only two roles of education in their life. First, many community people perceived role of education for them was nothing more than getting literacy skills: read and calculate. Second, some other people thought that school education was useful to increase the little hope of getting the low level of job. However having simply the school level certificate had no guarantee of getting a job. It needed to have a good network or to bribe the people who were in power. In order to materialize these two aspirations, grade 8 was enough so they were not bothered for completing school level education. However a very few community people considered school education as a foundation for higher education to lead to gain power, prestige and property. In this regard, I argue that mandating technical and vocational education in secondary level education that helps not only to fulfill the basic aim of education of developing employability among school graduates but also enhance the efficiency and outcome of school education system.
\end{abstract}

Keywords: Tamang people, school dropout and TEVT

\section{Background}

Education is understood not only as a means of development but also the ends of development. Education enables and empowers individuals by enhancing their productivity leading to achieve a better employment and income and ultimately to enjoy a quality of life. Education can be seen as instrumental in individual's freedom as it enhance 
their personal role, social role, processing role, empowerment and distributive role (Sen and Dreze, 1999). Thus, education has been globally accepted as a basic human right in the modern world for last several decades. Nepal's political processes, as well as development initiations, have been also guided by this basic philosophy of education. Each successive constitutions of Nepal have emphasized the greater role of state for peoples' education. The present constitution of Nepal states "Every citizen shall have the right to free education from the State up to the secondary level as provided for in the law" (Government of Nepal [GoN], 2015). Likewise, starting from the concept of free primary education in the first plan (National Planning Commission [NPC], 1956) to present periodic plan (NPC, 2013) the state envisions to give education to its citizen. The School Sector Reform Plan (SSRP), current main education plan of the country, views to ensure equitable quality basic education for all children (Ministry of Education [MoE], 2009) whereas the new education plan, the School Sector Development Plan (SSDP, 2016-2023) also envisions free and compulsory basic education (MoE, 2016) in the country.

The state has not only highlighted the state's high priority in education in its policy documents, it has been also materializing this policy by allocating more and more budget on it. For last two decades, the state is spending the largest share of public expenditure in the education sector where almost three fourth of education budget goes for school education (MoE, 2015). A huge amount of money is spent for free tuition fee and free textbooks to all, and scholarship, free uniform and day meal to socio economic and geographically disadvantaged children (MoE, 2013).

Despite various program and policy intervention in education targeting the disadvantaged group, still, 42.6 percent of women are illiterate in the country (MoE, 2015). Among 6 years and over, 34 percent of the population is found never stepped in school (Central Bureau of Statistics [CBS], 2011). National
Census carried on 2011 revealed that out of total 8 million children of aged 5-16, 1.2 million (15\%) children were not attending schools where in some Terai districts this percentage was more than 25 percent. Likewise, the national statistics showed that out of one hundred children enrolled in grade one, 6.5 children drop out from the same class and the rate of drop out in each grades ranged from 3 to 6 percent (MoE, 2015). The average SLC (national exam taken after grade 10) pass rate in the country has remained less than 50 percent for the last couple of years. It means, only one third of children can complete school level education. On the top of this, due to lack of job in the national market, thousands of young Nepali goes to India, Malaysia and Golf country as an unskilled labor force. The total number of workers gone for foreign employment since mid1990s has reached almost three million (Ministry of Finance $[\mathrm{MoF}], 2013)$ who are mostly engaged in 3 $\mathrm{D}$ (difficult, danger, dirty) work due to lack of technical skill.

The above statistics show that many children in Nepal could not complete school level education but only some of them completed school level education. Those who completed school could not get employment opportunity in the country and compelled to go abroad for a hard and difficult labor work. Thus, the huge investment made in education sector is not giving the expected return to both individual and state. The people have been getting less benefit of education are from poor strata of economy, remote area, and low caste families or of disadvantaged ethnicities, as well as children with disabilities (DoE, 2014).

The main objective of this field based study was to explore perception of dropout children and their parents, despite the state's high effort. The various research studies conducted on school dropout showed a long list of factors related to school and household to culture of the people to peoples' perception of education responsible for the school dropout (JICA/CASP, 2004; IREWOC, 2007; Kushiyat, 2009; DOE, 2012). One of the noticeable findings of 
literature review revealed that that the reason for dropout identified by various research studies have not been altered since the last couple of decades. There was not much difference between the studies conducted during the early 1990s or in recent years (IEES, 1993; JICA/CASP, 2004; DoE, 2012). Despite presenting multiple reasons of OOSC, some were found highlighting school related factors (Acharya \& Giri, 2009; Wagle, 2012) and socio economic condition of the society and family (Kushiyait, 2009; DOE, WE \& UNICEF, 2011; DOE, 2012). The dropout problem seemed to be more closely related to socio-economic and family factors than the factors within the educational system (DOE, 2012). But the reasons were different for different group of peoples such as girls, dalits, ethnic people where the prevalence was comparatively high among these groups of people. (JICA/CASP, 2004). On the top of this, an ethnographic study conducted in a small ethnic community of Tamang people revealed that the relevancy of school level education realized by the poor and disadvantage section of population to their life of was the main reason behind the drop out. If they had found the education as relevant ensuring employment and earning, they could manage other obstacles.

\section{Research Site and Methodology}

I carried out an ethnographic field work in a Tamang community near Kathmandu. The community was located in hilly rural area, and it took nearly two hours walk climbing up the hill to reach in the community from the bus station crossing the dense forest. Agriculture was the main occupation of majority of the community and the subsistence level of agriculture was not enough to run their livelihood for most of the families. As a result, many families were engaged in making alcohol at their home and selling in the nearest market as second occupation which was a regular source of income for them. Very few were also engaged in small business and Nepal army as well.

There was one primary and one lower secondary school in this area. The children needed to step down two hours to low land for the secondary level education. The people with 50 plus age group were hardly found literate who had never been to school. But at present every child was found to be admitted in school at some point, many of them were out of school after few years of schooling.

I did the cohort study in the beginning of the research and found a very low efficiency of the education system. Out of total 22 children enrolled in grade 1 in 2004, after 10 years only 2 were found able to reach grade 10 in 2013 where 4 of them were in grade 9 . The rest of the students had left school at different grades. Despite some improvement found in other successive years, the cohort study done for other years revealed a very high dropout rate in the area.

Generally, there was a tendency of going school at the late age. Consequently, many children studding in grade 7 or 8 were found of age 15 or 16 or even older. Once they reached to this age there was a tendency to leave school either to engage in household occupation or in search of work. The youth had a great attraction to government service especially in Nepal army. Majority of the boys after completion of grade 8 were found trying to enter into army service. If they could not enter into army then they would try to go abroad for labor work. In case of girl, early marriage was a common practice. Becoming a mother of baby at the age of 16 or 17 was not surprising. School after marriage was almost impossible for girls.

In this regard, in addition to prolong observation of the community, I interviewed some community people and conducted a couple of focus group discussion with teacher and student to understand their experience and general perception on education. Likewise, I selected six dropout children and their parents for several rounds of in depth interview to explore their lived experience on the roles of school education in their life and perception constructed on their mind. 


\section{People's aspiration from education}

In ancient and medieval times, schooling in Nepal was considered as a family affair rather than the state's responsibility (Sharma, 1986). But after the establishment Darbar School in 1954, people gradually exposed to the role of education. As all the school graduates of that period were employed in some administrative work in government (Bista, 1991), despite the policy of controlled expansion of access to education adopted by Ranas, general people had opened some schools on their own in late 1940s (Onta, 2000). Likewise, after the planned development initiation in late 1950s and 1960s, as white and blue color job were rapidly created (Bista, 1991), the entire educated person got job in government as they were scarce. People were interested in government job as it was basically table work, easier than the agriculture work and also the symbol of power and prestige (Bista, 1991). Historical event was the exposure to people to construct educational aspiration. The general people of Nepal have been guided mainly by three educational aspirations. First, the common people are not happy with their traditional occupation such as agriculture and animal husbandry which needed hardship of labor. It is labor intensive work, subsistence in nature. Thus, historically schooling meant occupational mobility from their traditional type of manual and hard physical work to nonmanual and easy table work in civil service (Shrestha, 1998).

Second, the people from rural and remote area are historically seemed to be interested to shift to more comfortable ways of living from hardships of rural areas. In this regard, education became a means to give employment and income that gives basis for survival to adjust in new migrated areas. One can find that the educated people of the country have been permanently migrating from villages to urban areas and capital cities for last couple of decades. Third, people, naturally, are fond of acquiring power, prestige and property for an upgraded social status. Historically, the education was the priority of elite people as it would help them to enter into the government job and enjoy power and prestige with white color job (Bista, 1991). These motives are still valid for common people to gain power, prestige and property by entering into government service. Historically, poor and disadvantaged people of Nepal had less concern with education. Neither the education was accessible to them nor was the government jobs approachable to them. Thus, education was not thought by them as their business which resulted a significant numbers of marginalized populations out of school for a long period. As a poor and disadvantage group of people, this national scenario was true for those Tamang people of my research site as well. There was no school at all in this area till 1970s and the people above 50 years old were rarely found literate. They were engaged in totally in agriculture and animal husbandry occupation. In addition, cutting tree from forest and selling it at near market and working as agriculture labor at the adjoining villages were the additional work for income. These people never thought the role of education to their life.

With the availability of school in their area, state's various efforts to bring them in school and their gradual exposure to the outer world, these Tamang people were also found gradually following the trend general people of the country. They were also found having a wish to shift their traditional occupation which they disliked in many ways. The agriculture was neither giving them enough food nor was it the source of regular income. Moreover, it was demanding their labor for the whole year, including the engagement of their children. This compulsion made the children's engagement in agriculture from early age as both practice and tradition. This was more applicable in case of rural population, economically poor people and girl population (DoE, 2014; IREWOC, 2007; UNICEF, 2014). In such circumstances, sending their children to school was a great sacrifice to parents rather than sending them to work. Even in such condition they had sent their children school with some ideal role of education. On the other hand, even the GON claimed free and compulsory education it was not free in real sense. 
People had to pay both direct and indirect cost while sending their children to school. It was difficult to afford education with their low income and poor economic condition. Nevertheless, the education would not necessarily give them job, as it was essential to have linkage (afnomanchhe) with power (Bista, 1991) or need to bribe the people who were in power. In such condition the opportunity cost was higher for them who could send their children to work rather than to school for study. For them investing in education was simply the loss of time and resource including the opportunity cost. The community people had any examples of school or college graduates getting back to their traditional occupation. There was a dilemma between "a bird in hand or many birds in bush" - the immediate and confirmed benefit from labor work or invest more in education hoping better future.

Based on their personal experience, exposure and family's economic condition, the subjective judgments on objective reality of the situation, these ethnic people were found with three levels of aspiration from education.

\section{Lowest level: Education for literacy}

Dukhi Tamang, who went to school but could not completed grade 1, never thought to send his children above grade 8 . His son left school when he was in 8 grade last year and then, he planned to go abroad after he failed to get a job in Nepal Army. This was the only option, they found, to pay back their loan which was taken in different incidents. Dukhi decided to drop her elder daughter from schooling from this year as his wife died last her and daughter needed to replace her in household chores including agriculture work. He had a further plan not to send his younger daughter to school after grade 8 who was now studding at grade 5 .

Dukhi sent all his children to school because education is an 'eye opener' and it makes people literate. He said that the role of daughter was to run the family life after marriage and this level of education was enough to perform that role. He was not regretting even at his son's dropout. He believed that even after education one needed to have afno manchhe (network) or bribe people to get job. This was his own experience during his son's effort to enter into Nepal army. He was happy with his son that his son will come back after two years with some money.

The lowest level of aspiration from education in the community was just to be literate in letter and numeracy. Many parents were found in the community with this lowest level of aspiration. The literacy was considered in the community as an essential component for the life of every people. This aspiration was built as the learning of their life experience where many parents had faced several difficulties due to their illiteracy. One mother of older age with two children shared her life experience, "People usually come to me to put my signature on some paper. I cannot read and always feel fear of risk of putting my signature on it. Moreover, I feel shame while putting my thumb signature on it as I cannot make a print signature. So I put my best effort to make my children literate" In addition the functional value of literacy in their daily life, the literacy of people was understood as the symbol of civilization as well. This group of people believed that education was no more helpful to get job as other network and relation was ore important. It was less benefitting to put more investment in educating their children because of lacking of such social and political capital. Thus, the best decision was to send their children up to that level where benefit of literacy was guaranteed. This was also guided by the cultural aspect of the people. The role of females was socially assigned and practiced as well limited to household chores and agriculture occupation. So, the aspiration of becoming literate from school level education was more associated with girls. The interaction with dropout girls and their parents showed that they were no more regretful of leaving school at lower grads as they had seen that some of their seniors who had completed higher level of education were also performing nothing more than what these dropouts were performing. 


\section{Intermediate level: Education for employment}

Shahasi Tamang was proud of her both children. Shahasi's daughter was 17 years old who had left school two years ago at grade 7 and got married. Now, she had become a mother a baby as well. Shahasi was satisfied with her daughter's education even she was left at grade 7. Her daughter was able to read, write and calculate with basic numeracy skill which she was lacking. This was what, she thought, a housewife needed to run her family comfortably.

Actually her son was about to leave school after grade 7 but she gave pressure him to complete grade 8. After grade 8 , she sent her son to a house of senior army officer to work as a house labor. He worked there for three years, served the army officer and could make him happy. As a result, he was able to become a 'sipahi' (the lowest position in military service) with the officer's power. Shahasi was happy that education gave her son a permanent job and regular source of income even on his retirement. Moreover, other community people treat her with respect and take her as a successful example.

The intermediate level of aspiration from education was to open a faint opportunity to employment. This category of parents considered literacy as necessary but not sufficient condition to run a family life. Only the area of government employment exposed to the community people Nepal army and completion of school education of grade 8 was the prerequisite to enter in the service. This aspiration was more associated with boys whose role was considered different from the girls - to look up also the financial aspect of family. For this, they should have some regular earning. These were the parents who were interested but not able to become army in their life. At the same time they had seen different life style of the army living in their village. Thus, a regular source of income and permanent employment was major expectation from education. The entry in Nepal army was also guided by some other motives as well. First, it a kind of occupational shift from the hard life of agriculture to a more comfortable filed of government service. Second, this occupation would give them regular income even after their retirement. On the other hand, the agriculture was giving them return only at the harvesting time. Third, becoming an army was also the symbol of prestige which had different position in the society from those of agriculture labor or some wage earner. Once a person entered into the army service (sipahi), it was possible to make some networking with the power which was opening the opportunity of employment for other family members as well. So most of the children of the community were found eagerly trying for army first and if it became impossible, then they were found looking to other field.

At the same time the children were experienced and exposed with their seniors who been back to same traditional occupation or looking for work even after having higher education. In this critical situation, the children had two options. First, make further investment in terms of resource, effort and time for further education which had not guarantee of giving them employment in future. Second, drop out school and start some work for earning. In such confusion, many people were found choosing the second option - preferring one bird in hand to many birds in bush. This was rational decision for them from cost benefit analysis aspect s well.

For these both educational aspirations, a completion of secondary level education was not felt essential. Further, to attend the grade 9 and 10, they needed to go down with two house walk to plain land. In addition, they needed to put more effort, time and resource for this level of education. Despite comparatively higher cost, nothing was guaranteed from completing school level education. So, on the given socio economic background of the community and the larger context of the society, the decision of dropout before completing school level education was rational decision for many parents. Thus, due to these low levels of aspiration for majority of people, there was high dropout rate in the community. 


\section{Highest level: Education for power, prestige and property}

Father of Firta Lama, a retired 'Sipahi' from Nepal army, thought that one should complete at least grade 12. He was committed to his perception so that he made his best effort to educate Firta till grade 12 . He sent his son to a rented a room to the city area for his higher secondary level of education, and fulfilled his desire. He had seen the life of senior army officer with power, prestige and property. In order to get that position, grade 12 was prerequisite. However, even after completing grade 12, Firta was unable to become an army officer. So he came back to the village and engaged in the same traditional occupation of agriculture and making local alcohol.

But, there were few parents who were who had higher level of aspiration from education than just making literate or just opening a little opportunity of employment. Those people expressed that grade 8 was not enough for a meaningful change in their life. If one was to release their children from their traditional lifestyle and occupation and enjoy a meaningful lifestyle, they should have a higher educational degree. Generally, this aspiration was associated with two categories of parents. First, the parents who joined army but in lower rank had exposed with the power, prestige and property of senior army officers. They had realized that it was possible for them as well but the prerequisite was to have at least certificate of the grade 12 . Second, the people who had been to abroad for labor work were experienced if they had better educational degree, they could get a more comfortable work and better income. Even people had this aspiration, many parents were not able to invest for higher education or they were not fully confident that higher education certainly gives them better return. This was so because, many youth with higher education had got back to community and engaged in the traditional occupation.

\section{Need of TEVT in school level education}

The role of education is considered important on the assumption that it helps people to enjoy a quality of life for which income and employment are the prerequisites. So the education should be viewed from the perspective of it's outcome in terms of creating employability in individual. Rather than making the individual simply literate and building foundation for higher level education to some extent, the existing school level education does not give any specific employability skill to start any work. In this regard, technical education and vocational training (TEVT) could be helpful in capacitating individual by giving employable skill for the world of work The high dropout rate in school level education especially among the poor and marginalized population was due to their low educational aspiration whereas the reason of low aspiration was due to the low relevancy of education experienced by them in their life. The educational aspiration of poor and marginalized population was limited to becoming literate and opening a faint hope of employment. This was the result of their low economic condition whereas the secondary education was not able to give any employment skill to them. As a result many children from such family were not motivated to complete school level education. In this line, TEVT can be one of the solutions.

Analyzing this issue from theoretical lenses, the root of present school system is the continuation of concept of mass schooling and considered to be rested on the foot of capitalization. This perspective argues that the role of education is to enhance the productivity of individual whereas the system payback according to their contribution. Thus, education helps resolve the strains of differentiations, with emphasis on the lateral dimension (Boli, Ramirez \& Mayer, 1985). But the school education was, except making literate the people, neither had created the employability on school completers nor had the educational credential of school graduates played important role in the status attainment (Stash \& Hannum, 2009). In this regard, the introduction of TEVT in school level education will help to materialize the capitalist view of school education. The left perspective blames that the mass schooling benefits. As it is for general people so by its basic 
nature, its basic character is institutionally universal, homogenous, standardized and rationalized, mass education in general, is not the practical device to deal with particular local problems or to address the needs of any specific group (Boli, Ramirej \& Mayer, 1985). Thus the marginalized section of population does not get benefits from education. The present school system fits only for the high class people who can see the future perspective of education (Parajuli, 2002) and also can afford it. In this connection introduction of TEVT in school education will be helpful to correct the weakness school education as identified blames of left on.

But as just opposite to lefts blaming to present education system, the state was found provisioning several facilities to increase the access of poor and marginalized in school system. Since the human right convention of 1948, all education forums have recommended the objective of reaching to more and more people and Nepal is accepting those agendas in favor of poor and marginalized. States implementation of Karachi convention of 1960s to present time EFA and MDGs ideas are its example. The state's plan and policies are providing one after another more privilege to the weaker section of population such as such as free school education, free test book and scholarship to bring the poor and disadvantaged population to school. But these provisions had been able to bring the poor and marginalized population just to the door of school but not able to give good return to them. In this endeavor, TEVT will strengthen the state's program and policy in ensuring the benefits to the poor and marginalized.

The field study showed that in case of poor and disadvantaged section of population living in a rural area and engaging in agriculture occupation, it was very difficult to continue their education after school level. Even to complete the secondary level of education, they had to sacrifice a high opportunity cost. On the other hand, they were experienced that the school level education was not able to give any employability skill. In such condition, it was natural to leave the school and look for any job that gives them income. As a result, there was found higher rate of school dropout in rural area and specially that poor and marginalized section of population. Conclusion

In the highly stratified society in terms of social, cultural and economic aspects with different capacities and capabilities, the education policy of providing piecemeal facilities such as free text book, uniform and small amount of scholarship might bring the marginalized family up to the school's door temporarily but it is not sufficient to retain them in school and to make learning outcome significant and relevant to their life. I see the mismatch between the poor and disadvantaged people's socio economic condition and the goal of school education system as the major problem. The school system views the students as a full time student whereas the parents are compelled to treat them as a full time worker. The school level education provides them simply the skill of literacy whereas only this skill is not enough to get employment in job market. The school level education is said free but the parents have to pay direct, indirect and opportunity cost for the education. As a result the parents find high investment in school education for nothing guaranteed benefits. All these anomalies lead to the parents and children to have a low level of aspiration from education which was the major reason for high rate of dropout.

Thus, incorporation of TEVT in secondary level education could be one of the solutions for various problems at the same time. First, the immediate effect would be the reduction of school dropout rate. The TEVT, a way of develop employability, would motivate both the parents and children to continue the school education so they there was high chance of getting employment in future. Second, as students get employment, it seems possible to bring both work and education together for further education ahead secondary level. TEVT not only increases employability of individual by giving them working skills but also enhances the entrepreneurship skill. Even in case of unavailability of market job, the 
school graduates could create job on their own. The TEVT is more relevant to that poor and marginalized section of population who cannot continue a longer time in education. For them, TEVT is a good means to gain working skill in a short span of time and starts to earn. More than this, now many Nepali youth are working in Malaysia and Golf countries as an unskilled labor at very low wage rate. If the TEVT in school education could make them semiskilled or skilled, there would be significant increase in remittance.

Thus, once the probability of getting job and their productivity after school education increases, it motivates the students to complete school level education which lead to increase in peoples' aspiration from education and decline in school dropout. However, the challenging administrative part and expensive financial part of TEVT introduction in school level education should not be undermined.

\section{References}

Acharya, S. \& Giri, D. (2009). Measuring learning achievement of Nepali and non Nepali speaking students of Dang district. Kathmandu: Save the Children Japan.

Bista, D. B. (1991). Fatalism and development: Nepal's struggle for modernization. India: Orient Longman.

Boli, J., Ramirez, F. O. \& Mayer, J. W. (1985). Explaining the origins and expansion of mass schooling. Comparative Education Review, 29(2), 145-170.

Central Bureau of Statistics. (2011). Nepal living standard survey 2010/11, Statistical report (Volume one). Kathmandu: Author.

Department of Education, World Education \& UNICEF (2011). Mapping out of school children: An analysis from 8 Terai districts of Nepal. Kathmandu: Author.
Department of Education, World Education \& UNICEF. (2011). Mapping out of school children: An analysis from 8 Terai districts of Nepal. Kathmandu: Author.

Department of Education. ( 2014). Consolidated equity strategy for the school education sector in Nepal. Bhaktapur, Nepal: Author.

Department of Education. (2012). A study on out of school children and verification of data. Bhaktapur, Nepal: Author.

Department of Education. (2013a). School level educational statistics of Nepal, consolidated report 2012 (2069). Bhaktapur, Nepal: Author.

Department of Education. (2013b). Strategy and action plan on bringing out of school children into basic education. Bhaktapur, Nepal: Author.

Government of Nepal. (2015). Constitution of Nepal. Kathmandu: Author.

Hannum, E. \& Buchmann, C. (2003). The consequences of global educational expansion: Social science perspectives. Cambridge, MA: American Academy of Arts and Sciences.

International Research on Working Children. (2007). Deprived children and education: Nepal. Retrieved fromwww.crin.org /docs/ Nepal_Education.pdf

JICA/CASP. (2004). A survey report on dropout children of Dhading and Siraha district. (A survey report submitted by Teacher Educators' Society - Nepal to JICE/CASP office). Kathmandu

Kushiyait, B. (2009). Social exclusion in education: A study on school dropouts in terai and hill districts of Nepal (A report submitted to SIRF Secretariat, SNV Nepal). Retrieved from: http://www.socialinclusion.org.np/new/files /Binay\%20Kushiyait_1336453822c2xY.doc 
Ministry of Education. (2009). School sector reform plan 2009-2015. Kathmandu: Author

Ministry of Education. (2013). School sector reform programme: Annual strategic implementation plan (Annual work plan \& budget, 2013-14). Kathmandu: Author

Ministry of Education. (2015). Nepal education in figures 2015: At-a-glance. Kathmandu: Author.

Ministry of Finance, (2013). Economic survey of Nepal, Fiscal year 2012/13. Kathmandu: Author.

MOE. (2016). School Sector Development Plan 2016 - 2023 (A draft policy report). Kathmandu: Author

Nepal Law Commission. (n.d). The interim constitution of Nepal, 2007. Retrieved from www.lawcommission.gov.np

National Planning Commission. (1956). Draft five year plan, A synopsis. Retrieved from http://www.npc.gov.np

National Planning Commission. (2013). An approach paper to the Thirteenth Plan (FY2013/14 2015/16). Kathmandu: Author.

Onta, P. (2000). Finding a ray of hope. Economic and Political Weekly, 35(47), 4093-4096

Parajuli, M. N. (2002). The state, the school, and the society: Dilemmas and crisis in education in Nepal. A PhD thesis submitted to Department of Educational Anthropology, The Danish University of Education.

Ramirej, F. O. \& Boli, J. (1987). The political construction of mass schooling: European origins and worldwide institutionalization. Sociology of Education, 60(1), 2-17.

Saha, L. J. (2008). Sociology of education. In (T. L. Good, ed.), 21st century education: A reference hand book. Thousand Oaks, CA: Sage Publication.

Sen, A and Derje J (1999). India: Economic Development and Social Opportunity, Oxford University Press

Shrestha, N. R. (1998). In the name of development: A reflection on Nepal. Kathmandu: Educational Publishing House.

Stash, S. \& Hannum, E. (2009). Who goes to school? Educational stratification by gender, caste and ethnicity in Nepal. In P. Bhatta (Ed.), Education in Nepal: Problems, reforms and social change. Kathmandu: Martin Chautari.

UNICEF. (2013). Situation analysis of out of school children in UNICEF-targeted districts of Nepal (an unpublished study report submitted to UNICEF Nepal).

Wagle, D. (2012). Dropouts of children from schools in Nepal. An unpublished MPhil thesis submitted to Norwegian University of Science and Technology. Retrieved from: http://ntnu.diva portal.org/s mash/get/diva 2:5607 2/FULLTEXT01.pdf 